\title{
MIDDLE OXFORDIAN AMMONITES (PERISPHINCTINAE) FROM KACHCHH (INDIA): BIOSTRATIGRAPHIC AND PALAEOBIOGEOGRAPHIC IMPLICATIONS
}

\author{
Jai KRISHNA ${ }^{1}$, Guillermo MELÉNDEZ ${ }^{2}$, Bindhyachal PANDEY $Y^{1}$ and Deo \\ Brat PATHAK ${ }^{1}$
}

'Dpt. of Geology. Banaras Hindu University, Varanasi, 221005 India.

${ }^{2}$ Lab. Paleontología. Dpto. Geología. Universidad de Zaragoza. 50009-Zaragoza, Spain

\begin{abstract}
Krishna, J., Meléndez, G., Pandey, B. and Pathak, D.B. 1996. Middle Oxfordian Ammonites (Perisphinctinae) from Kachchh (India): Biostratigraphic and Palaeobiogeographic implications. [Ammonites del Oxfordiense Medio (Perisphinctinae) del Kachchh (India): Implicaciones bioestratigráficas y paleobiogeográficas]. Revista Española de Paleontología, $\mathbf{N}^{0}$ Extraordinario, 140-147. ISSN 0213-6937.
\end{abstract}

\section{ABSTRACT}

The study of a rich Middle Oxfordian ammonite succession from Kachchh (W India) supplies new evidence to support the open biogeographic connections between the Submediterranean and Indo - East-African Provinces. The studied assemblage is precisely dated as Middle to Upper Transversarium Zone, (Middle Oxfordian), on the basis of representatives of Perisphinctes and Larcheria, this finding being the first record of this West-European form from India. The dating of the assemblage is further strenghtened by the occurrence of the tethyan form Gregoryceras.

Keywords: Biostratigraphy, Palaeobiogeography, Upper Jurassic, Indo - East-African Province, Submediterranean Province, Transversarium Zone.

\section{RESUMEN}

\begin{abstract}
El estudio de una sucesión rica en ammonites del Oxfordiense Medio del Kachchh (W India) añade nuevos datos en apoyo de la hipótesis de una conexión biogeográfica abierta entre las Provincias Europea e Indo-Africana oriental durante este periodo. El material estudiado ha podido ser datado con cierta precisión como parte media a superior de la Biozona Transversarium (Oxfordiense Medio) por la presencia de diversos ejemplares de Perisphinctes y Larcheria, constituyendo ésta la primera referencia de este género de afinidad europea en la India. La edad de dicho conjunto queda reforzada por la presencia del género tethysiano Gregoryceras.
\end{abstract}

Palabras clave: Bioestratigrafía, Paleobiogeografía, Jurásico Superior, Provincia Indo - Este-Africana, Provincia Submediterranea, Biozona Transversarium.

\section{INTRODUCTION}

The Kachchh basin is located in the extreme West of India in the state of Gujarat (Fig. 1). The region of Wagad represents the most proximal exposed part of the Jurassic sedimentay succession of the Kachchh basin, as one of its six principal upfaulted Jurassic domes amidts extensive plainland of younger age. The other five uplifted domes are: 1 : Mainland Kachchh; 2: Patcham "Island"; 3: Khadir "Island"; 4: Bela "Island" and 5: Chorar "Island".

Middle and Late Jurassic ammonite collections from Kachchh, West India, were known from the early works of Sowerby (1840), Waagen (1873-75) and Spath (1928-33). Remarkable progress has been achieved in the recent years (Krishna and Cariou, 1990, 1994; Krishna and Pathak, 1991, 1994; Callomon, 1993). The Oxfordian record, however, was mostly limited so far to the ammonite assemblage from the stratigraphically condensed Dhosa oolite unit, in the greater part of the Mainland Kachchh, spanning from Lower to earliest Middle Oxfordian. The recent finding of a relatively expanded Midd- le Oxfordian succession (Krishna et al. 1994) in the most proximal part of the Kachchh basin, at the locality of Wagad, East of the Mainland Kachchh, has allowed the bed-by-bed collection of thirteen stratigraphically successive ammonite assemblages. The studied ammonite collection comprises over 300 specimens belonging mostly to the geographically restricted Indo - East-African Mayaitinae and Tethyan Perisphinctinae in roughly equal proportion to the extent of $90 \%$. The rest of the groups represented (10\%), include some representatives of Euaspidoceratinae, and some few Oppeliidae and Peltoceratinae, as well as some scarce, large-size representatives of Liostraca ammonoids (Phylloceratina and Lytoceratina).

\section{RECENT PROGRESS IN THE JURASSIC STRATIGRAPHY OF KACHCHH}

The early ammmonite systematic studies by Sowerby (1840); Waagen (1873-75) and Spath (1928-33) invariably 


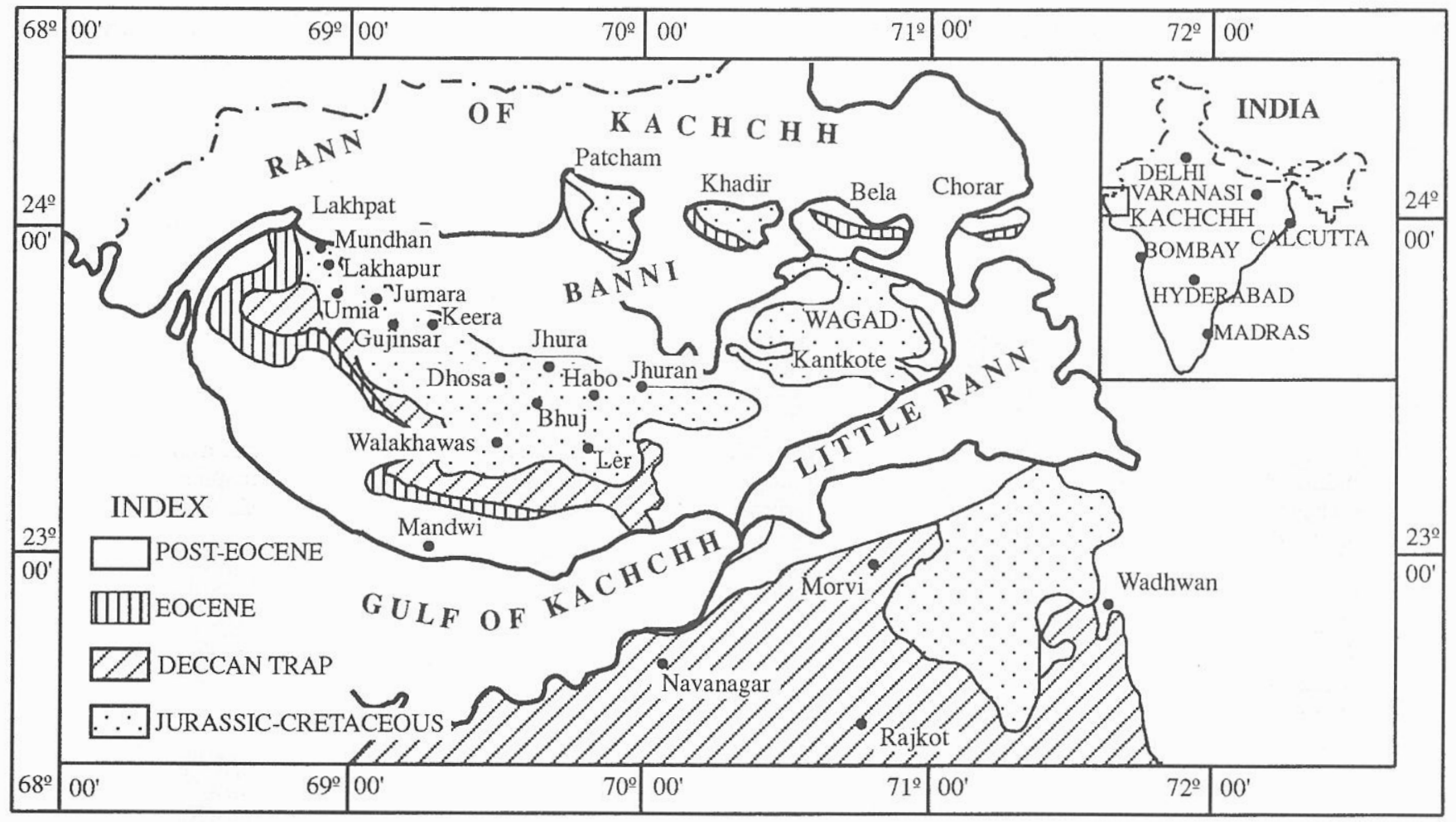

Figure 1. General geological setting of the studied Kachchh area (NW India) and geographical location of the main localities mentioned in this study.

lacked precise stratigraphic information on the taxa described yet made the Kachchh jurassic succession of primary importance in global context. In the recent years a detailed recording of the sections and ammonite biochronologic studies have been undertaken under precise bed-by-bed stratigraphic collecting. This has led to a remarkable improvement in the stratigraphic resolution (Krishna and Cariou, 1990, 1994; Krishna and Pathak, 1991, 1994). More recently, detailed ammonite zonal schemes have been proposed for the Callovian, Kimmeridgian and Tithonian stages in Kachchh for the Indo - East-African Province by Krishna et al. (1994; Fig. 2).

\section{OXFORDIAN STRATIGRAPHIC DEVELOPMENT IN KACHCHH}

\section{Lithostratigraphic framework}

A rich Middle Oxfordian uncondensed succession has been recently reported by Krishna et al. (1994) in the farthest exposed proximal part of the Kachchh Jurassic basin, at the locality of Wagad. The studied Oxfordian succession is localized at the uppermost ten meters of the Washtawa Formation (Biswas, 1977). Acording to this author, the Washtawa Formation consists of cross-bedded massive sandstones in the middle while its lower and upper portions are made up of alternations of thick-bedded sandstones and gypsiferous shales. This unit would broadly represent a lateral equivalent, in the proximal part of the basin, to the Chari Formation, in the widely used fourfold lithostratigraphic framework of Stolicz- ka (in Waagen, 1873-75), applicable to the Kachchh basin (Fig. 3). The Chari Formation established in the Mainland Kachchh, with the implied type locality at Keera, is otherwise dominantly shaly in character, particularly more and more westwards towards the distal part. This unit is abundantly fossiliferous throughout. It has provided a rich Callovian to Lower Oxfordian ammonite succession in many sections across the Mainland Kachchh. These ammonite assemblages were the main subject of the classic monographs by Waagen (1873-75) and Spath (1928-33). The Washtawa Formation, in contrast, is much less fossiliferous, the ammonite record being restricted to the uppermost ten meters of the unit, whence comes a rich Middle Oxfordian ammonite association. So far no record of Callovian or Lower Oxfordian ammonites has been reported from the rest of the unit.

\section{Stratigraphic relations between the Dhosa oolite and the Washtawa Formation}

The Oxfordian record in Kachchh has so far been limited to the so-called Dhosa Oolite, a highly condensed interval ranging in thickness from few tens of centimeters to a maximum of 6 to $7 \mathrm{~m}$ inclusive of a part in the underlying shales (Fig. 3). On the basis of the ammonoids enclosed, only Lower and the earliest Middle Oxfordian is found (Krishna, 1990, 1992; Krishna et al., 1994). Interestingly, in the greater part of the basin the condensed Dhosa oolite is followed up by a non-depositional hiatus extending up to Lower Kimmeridgian, Hypselocyclum Zone (Krishna and Pathak, 1991, 1994) from the extreme distal exposed part in Lakhapur to, at least, Habo for about $100 \mathrm{~km}$. 
W

MAINLAND KACHCHH

LAKHAPUR

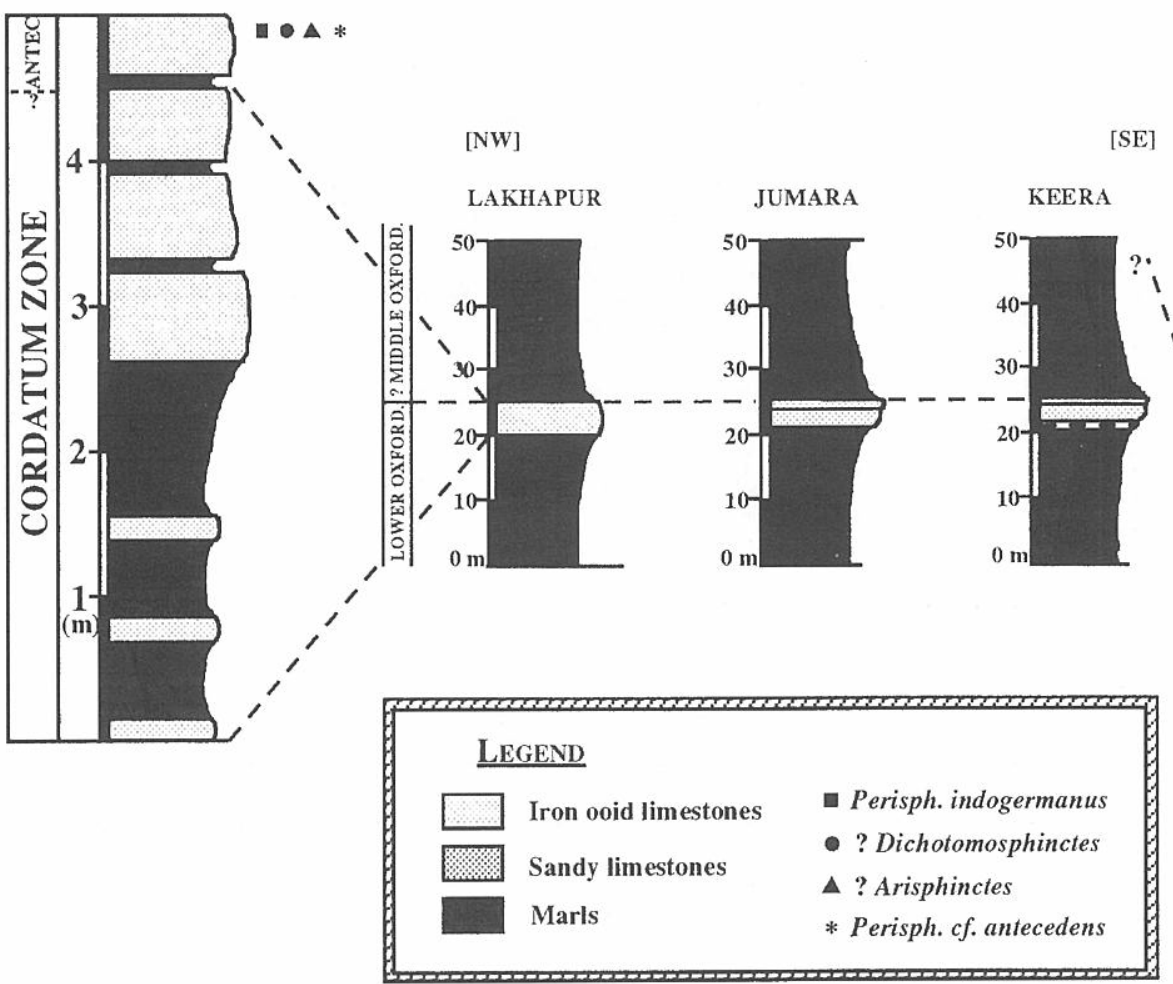

E

WAGAD

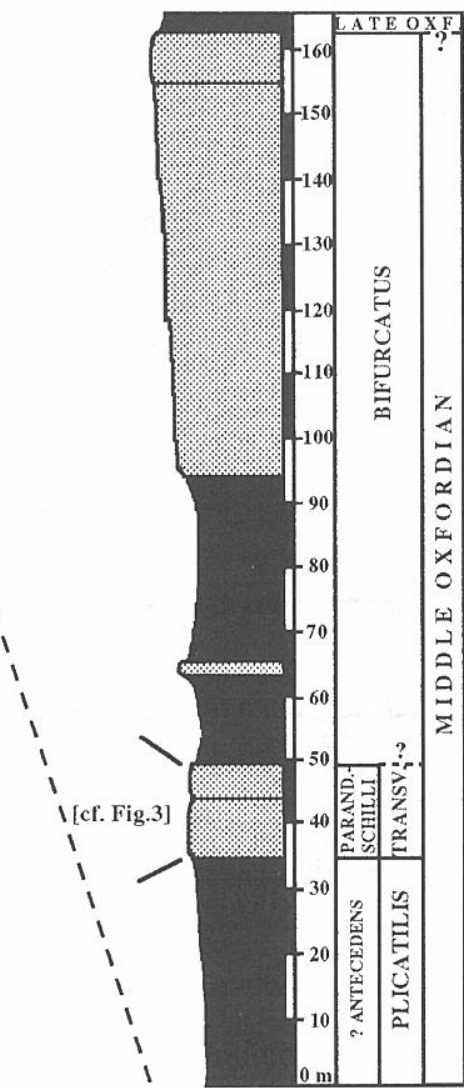

Figure 2. General stratigraphic correlation for the lower to middle Oxfordian rocks between the Mainland Kachchh (chari Fm) and the Wagad area (Washtawa Fm, pars.). The Dhosa oolite in all studied localities at Mainland Kachchh contains a rich lower Oxfordian ammonite succession which allows an excellent correlation across this basin. At Lakhapur, an uppermost association within this interval containing Perisphinctes $c f$. antecedens Salfeld and some related Perisphinctinae allows dating this upper part of the Dhosa oolite, as, roughly, Plicatilis Zone, Antecedens Subzone. At Wagad, the here studied Transversarium Zone ammonite succession has been recorded in a correlative, much higher levels (see Fig. 3).

Krishna et al. (1994) have given a succession of five ammonoid assemblages in the Dhosa oolite. The first four of these five assemblages are included in the Lower Oxfordian while the youngest has been suggested to possibly belong to the Vertebrale - Parandieri Subzone interval according to the evidence provided by the recorded taxa: Perisphinctes indogermanus Waagen, Arisphinctes sp., Dichotomosphinctes sp. and Subdiscosphinctes sp. However, at a species level, not a single form in this assemblage has been found to show either european affinity or common features with the Middle Oxfordian of Kantkot. Yet, a few nuclei of Perisphinctinae show a style of ribbing closer to the Middle Oxfordian Perisphinctes antecedens-buckmani group. It cannot therefore be excluded that the lower part of the Middle Oxfordian is partly represented within the Dhosa oolite. This in turn means a slight overlap of this youngest Dhosa oolite assemblage with the oldest level of the Kantkot succession at Wagad.

Oxfordian ammonites from Kantkot and the neighbour areas were widely monographed by Waagen (1873-75) and Spath (1928-33) in their extensive works. These valuable palaeontological works lacked, however, any precise stratigraphic information about the taxa described. The sedimentary column in this locality is about $300 \mathrm{~m}$ thick and the described taxa obviously may have come from different levels of this interval. Waagen assigned them to the Transversarium Zone. Spath ranged them from Transversarium to Bimammatum Zone. Arkell (1956) in his review assigned the Kantkot ammonites to the Bimammatum Zone. Biswas (1977) dated them as Argovian and correlated the Kantkot Middle Oxfordian ammonites to the Lower Oxfordian Dhosa oolite of other sections.

\section{Middle Oxfordian succession from Wagad}

In this context the recent discovery of a non-condensed Middle Oxfordian ammonite succession at Wagad, near Kantkot has assumed considerable significance. In addition to the Middle Oxfordian ammonite succession studied here, the $200 \mathrm{~m}$ thick sedimentary succession recorded upwards the Middle Oxfordian beds might presumably represent the remaining stratigraphic interval until the Oxfordian-Kimmeridgian boundary. This would be evidenced by the record of scarce badly preserved Perisphinctid assemblages in a succession of five distinct levels yet without a single mediterranean or submediterranean element for precise age determina- 


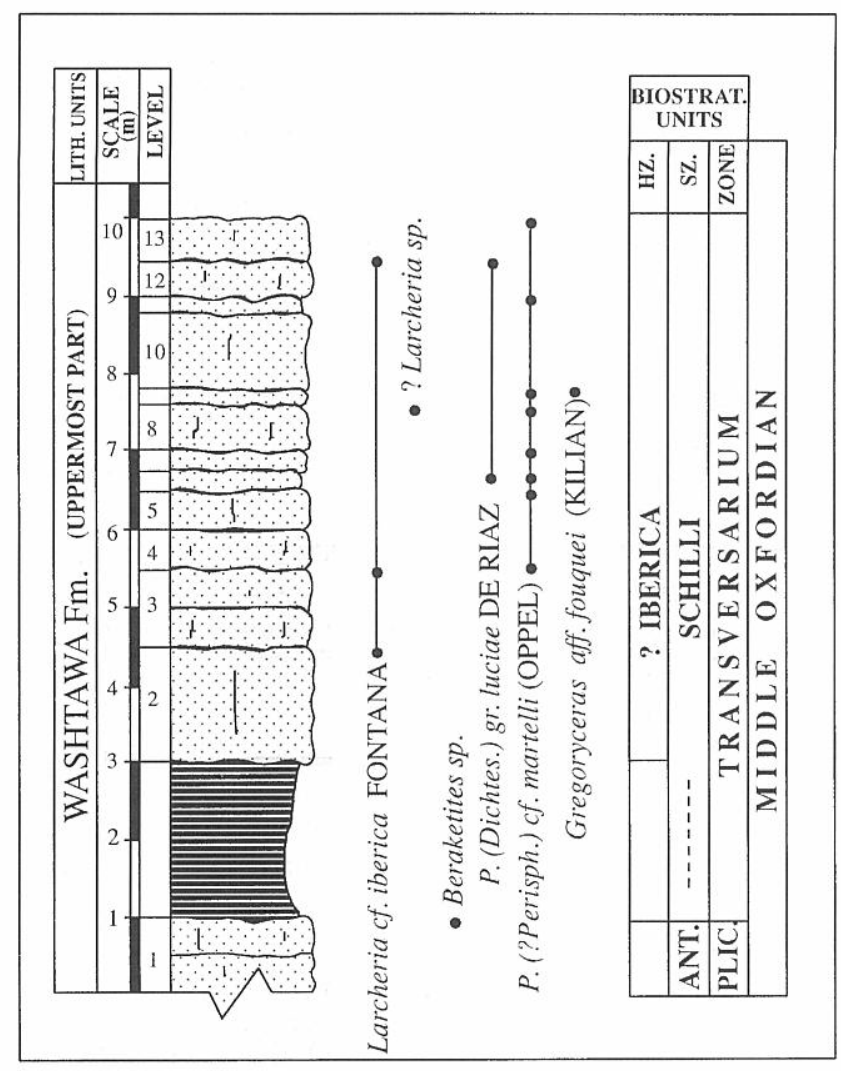

Figure 3. The stratigraphic succession of the Middle Oxfordian studied interval near Wagad (Kachchh, India).

tion, this ammonoid compositional difference between the Middle Oxfordian and these referred upper assemblages being also worth noting.

Ammonite-bearing beds are exposed along a small stream. Ammonites are collected in a well-defined thirteen-level succession of regular, brick red calcareous sandstone levels almost stacked one over the other with rare thin shale layers in between (Fig. 4). According to the primary analysis the ammonite spectrum is heavily skewed in favor of the geographically restricted Indo - East-African Mayaitinae and the Tethyan Perisphinctinae along with minor to accessory Phylloceratida, Haploceratidae, Aspidoceratidae, most specially the stratigraphically significant Peltoceratinae genus Gregoryceras. Representatives of Perisphinctinae include a few specimens of the north Tethyan genus Larcheria which mark the first stratigraphically precise occurrence of this genus on the Indo - East-African Province apart from a few references made to Collignon' (1959) madagascan forms by Tintant (1961) and Enay (1966). These occurences are here discussed in the overall palaeontologic, biostratigraphic and palaeobiogeographic context.

The recorded Middle Oxfordian interval contains a rich ammonite assemblage including Perisphinctinae, Peltoceratinae, Aspidoceratinae, Taramelliceratinae and the geographically restricted Mayaitinae while the latter interval relatively much poorer in ammonites contains only Perisphinctids, also of rather restricted character. This compositional difference explicitly suggests restricted palaeogeographic conditions and, possibly, bathymetric decrease

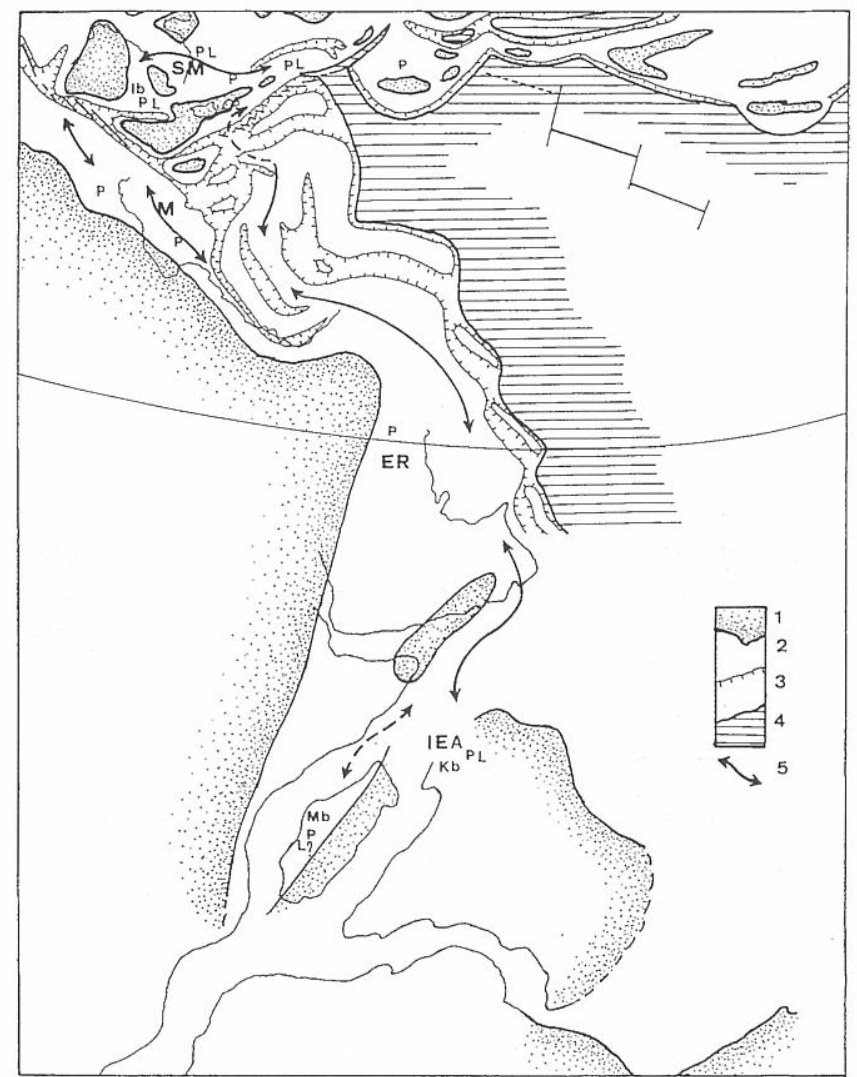

Figure 4. Paleogeographic sketch of the Tethys for Upper Jurassic times (c. Oxfordian) showing the inferred expansion of Larcheria between Southwest Europe and Indo-EastAfrican Province, presumably along the borders of emerged massifs and shallow platforms of northern and, partly, southern slope of Tethys. Partly based on Cariou et al. (1985) and Krishna \& Cariou (1990), according to the paleogeographic reconstruction in Dercourt et al., 1985). 1: Emerged areas; 2: Epicontinental seas; 3: Continental margin of oceanic areas; 4: Oceanic trough areas; 5: Possible expansion ways for Larcheria. SM: Submediterranean Province; M: Mediterranean Province; ER: Erithrean Province; IEA: Indo-East-African Province; Ib: Iberian basin; Mb: Madagascan basin; Kb: Kachchh basin. P: Perisphinctes; L: Larcheria.

after having reached a maximum in the Jurasic of Kachchh in the Middle Oxfordian Transversarium Zone. Apart from these intervals rich in ammonites, the entire $300 \mathrm{~m}$ thick succession in Kantkot at Wagad is devoid of ammonoids. The Middle Oxfordian interval at Kantkot is also found to be the richest in ammonites in the whole Jurassic-Cretaceous succession of Kachchh.

Concerning the correlation with the European submediterranean Middle Oxfordian a remarkable progress has been achieved in the recent years in the refinement of the ammonite biostratigraphic scale (Callomon, 1988; Meléndez, 1989; Cariou and Meléndez, 1990, Cariou et al., 1991; Meléndez and Fontana, 1993). The Middle Oxfordian, above the Lower Oxfordian Cordatum Zone and below the Upper Oxfordian Bimammatum Zone includes three biozones subdivided into eight subbiozones and and numerous biohorizons of which some are still of restricted geographical extent (Fig. 3; cf. 
Meléndez and Fontana, 1993). The occurrence of some representatives of the genus Larcheria close to the schilli (Oppel) - iberica Fontana groups in the greater part of the studied ammonite succession of Kantkot has led us to tentatively assign this stratigraphic interval to the middle-upper part of the Transversarium Zone.

\section{Ammonite associations}

The recorded stratigraphic succession forms a monotonous series of red clastic cemented calcareous sandstone beds stratified in regular decimetric, mostly $20-50 \mathrm{~cm}$ thick banks. The basal bank (level Nr. 1) is capped by an irregular surface and has yielded a middle-size $(100 \mathrm{~mm})$ adult specimen of Beraketites (m) sp. showing evolute serpenticone coiling, coarse ribbing and thick to depressed section. This bank is followed by $1 \mathrm{~m}$ thick marly interval. The overlying carbonate sandstone succession has yielded a rich Perisphinctes assemblage and, most remarkably, some specimens of Larcheria and the tethyan Peltoceratinae genus Gregoryceras.

From level 2 comes a fragmentary specimen showing oval section, somewhat involute coiling and multidivided distant ribs with a slightly developed smooth band on the point of furcation, referable to Larcheria (M) close to the schilli (Oppel)-iberica Fontana group. Level 3 has yielded a similar, more complete specimen, although a septate macroconch. Above levels 4 and 5, poorer in ammonites, levels 6 to 8 contain a rich Perisphinctinae assemblage including both numerous finely ribbed regularly biplicate Perisphinctes and some evolute crassicostate, massive specimens, showing early trifurcations, difficult to place in any microconch of Perisphinctes. Elements of the first group are mainly incomplete microconchs and nuclei of macroconchs. They show evolute coiling and quadratic to compressed whorl section with flat sides. They appear closest to Perisphinctes (Dichotomosphinctes) of the luciae De Riaz group and to Perisphinctes (M) kiliani De Riaz group. This would indicate a Middle to Late Transversarium Zone age, probably, Schilli Subzone. A single adult, incomplete, septate Perisphinctes (M) specimen shows thick single ribs in the middle whorls and the beginning of the variocostate stage at $270 \mathrm{~mm}$. diameter. Attention should be paid to some common septate macroconchs from this interval showing somewhat involute coiling, discoidal shape and ribbed, polyfurcate, non-variocostate outer whorl, difficult to match any Perisphinctes (M) from the Submediterranean Province. They cannot be assigned, however, to the close form Perisphinctes leyocimon Waagen either, since this form shows a very different multidivided, polygyrate to fasciculate ribbing. This assemblage also includes few, nearly complete, adult macroconchs of Larcheria. They show a somewhat evolute coiling, discoidal shape with compressed whorl section and blunt ornamentation, with distant umbilical ribs and a well-developed smooth band on the flank of the adult body chamber, at the bifurcation point. The adult size ranges from 250 to $280 \mathrm{~mm}$. (cf. Meléndez and Fontana, 1992).

Also from level 8 come some few, incomplete specimens of Gregoryceras. Level 9 has yielded a fine complete adult, coarsely ribbed specimen of Gregoryceras showing tuberculate ribs, mostly looped along a periumbilical row of tubercules. This makes it closest to the species Gregoryceras fouquei Kilian, except for the ribs on the flank being flexuous and retroverse and the whorl section, strongly trapezoid with concave sides. Hence it can be better interpreted as a primitive representative of this species, intermediate between Gregoryceras transversarium and Gregoryceras fouquei.

From level 10 comes a further coarsely ribbed perisphinctid showing very thick and depressed whorl section and early trifurcations. Although probably a macroconch nucleus it is morphologically closer to the typical madagascan Perisphinctinae (i.e. Beraketites and close forms) than to any submediterranean Perisphinctes.

Levels 11 to 13 contain again a rich, finely ribbed regularly biplicate Perisphinctes assemblage showing a wide variability, from involute to evolute coiling and fine biplicate and single ribs gently inclined forward on the whorl side. Yet the distinct forward sweep of secondaries on the venter, typical of such forms as Perisphinctes (Dichotomosphinctes) wartae Bukowski or Perisphinctes(Dichotomoceras) from top Transversarium Zone, Rotoides Subzone to Bifurcatrus Zone is still not present. Attention should be paid to the presence in the level 12 of a further typical specimen of Larcheria, also a macroconch nucleus, showing evolute coiling and compressed whorl section, close to the Larcheria iberica Fontana group, from the Schilli Subzone.

\section{BIOSTRATIGRAPHIC AND PALEOBIOGEOGRAPHIC REMARIS}

The first recorded level, containing Beraketites sp. (Collignon, 1959, Pl. LIX, fig. 276) probably corresponds to the early Middle Oxfordian. Following Enay's (1966, p.446) discussion on Otosphinctes and Beraketites this specimen shows consistent similarities with Perisphinctes (Otosphinctes) siemiradzkii Enay and it might indicate late Plicatilis, Antecedens Subzone, to early Transversarium, Parandieri Subzone age.

Above the discontinuity the carbonate succession containing Perisphinctes close to the luciae-kiliani De Riaz groups and Larcheria belongs to the middle Transversarium Zone. Beds containing similar ammonite assemblages across the western Tethys are traditionally placed in the submediterranean Schilli Subzone. However, taking into account the lack so far of typical Perisphinctes (M) of the martelli Oppelcuneicostatus Arkell groups among the studied assemblages and the frequent homeomorphies the representatives of Perisphinctes may show, it seems that such precise biostratigraphic correlation between these distant areas should not be taken without some reservation. The upper part, from levels 8 and 9 yielding some well-preserved Gregoryceras intermediate between Gregoryceras transversarium (Quenstedt) and Gregoryceras fouquei (Kilian) might represent the late Transversarium Zone (Fig. 3). However, further evidence is still needed from the Perisphinctes assemblage.

The studied ammonite associations from Kachchh support the open biogeographic connections during the Middle Oxfordian between the two margins of the Tethys (Submediterranean and Indo - East-African Province: Fig. 4). Biogeographic connections with the Submediterranean Province are stressed by the record of the West-european taxon Larcheria. Connections with the Mediterranean Province are underlined 
by the record of the biostratigraphically significant taxon Gregoryceras and by the clear similarities with the Middle Oxfordian of North Algeria, at the Bechtout and Bou Redou regions (Tellian Basin), as shown by Atrops and Benest (1986, 1994). It should, however, be remarked the constant absence so far among the studied material of any representatives of the genus Passendorferia and related forms (subfamily Passendorferiinae Meléndez). The presence of some large-size representatives of Liostraca (Phylloceratina and Lytoceratina) in minor proportion stresses the open biogeographic connections of the studied area with the oceanic areas of Tethys which should, most probably, favor the taphonomic dispersal of drifted shells into the Kachchh basin (cfr. Fernández-López and Meléndez, 1994). The already known close biogeographical relations with Madagascar, based on the common presence of Mayaitinae, are further strenghtened by the record of the Madagascan taxon Beraketites.

\section{CONCLUSIONS}

Unlike the western part, Mainland Kachchh, in the Kachchh Basin the eastern, internal part of the basin at the Wagad region during the Middle Oxfordian was an open, sandy carbonate platform. Beyond the development of biogeographically restricted, endemic ammonite groups biogeographic connections with western Tethys were clear. They took place most probably through shallow areas along the southern margin of the Tethys. The finding of a rich Middle Oxfordian ammonite succession at the terminal part of the Washtawa Formation facilitates the litho and biostratigraphic correlation between the Mainland Kachchh and the Wagad region. The analysis of the Middle Oxfordian ammonite succession has allowed dating the studied stratigraphic interval as middle to upper Transversarium Zone. Some recorded taxa such as the west-tethyan form Larcheria and the southtethyan form Gregoryceras strenghten these biostratigraphic datings and the so far hypothetical biogeographic expansion of these forms towards the Indo - East-European Province.

\section{ACKNOWLEDGEMENTS}

Thanks are due to Prof. J.H. Callomon for suggestions and discussions, and to Julia Bello and Isabel Pérez Urresti for their help in making the graphics. The project benefitted from financial support by the CSIR (India) and from a special Marie Curie research award by the European Community. This paper is a part of the research project PCB-94 from the Gobierno de Aragón (CONAI), Spain. The authors would like to thank as well two anonymous referees who made a critical reading of the manuscript and helped much to improve the final version of this paper.

\section{REFERENCES}

Arkell, W. J. C. 1956. Jurassic Geology of the World. Oliver and Boyd edit., Edimburgo, 806 p.

Atrops, F. and Benest, M. 1986. Stratigraphie du Jurassique supérieur du Djebel Bechtout au Nord Ouest de Tiaret (bordure sud-tellienne, Algérie); comparaison avec le Bou Rhedou. Geobios, 19 (6): 855-862.

Atrops, F. et Benest, M. 1994. Les formations à ammonites du Malm dans le Bassin Tellien, au Nord de Tiaret; leur importance pour les corrélations avec les séries de l'avant-pays de l'ouest algérien. Geobios M.S. 17: 79-91.

Biswas, S. K. 1977. Mesozoic rock-stratigraphy of Kutch, Quart. Jour. Geol. Min. Met. Soc. India, 49, (3-4):1-50.

Callomon, J. H. (1988). The ammonite successions and subzones of the Transversarium Zone in the submediterranean Middle Oxfordian. Proc, 2nd. Int. Symposium on Jurassic Stratigraphy, Lisboa, 433-444.

Callomon, J. H. 1993. On Perisphinctes congener Waagen, 1875, and the age of the Patcham limestone in the Middle Jurassic of Jumara, Kutch, India. Geol. Bl. NO-Bayern, 43 (1-3): 227-246.

Cariou, E., Contini, D., Dommergues, J. L., Enay, R., Geyssant, J., Mangold, CH. et Thierry, J. 1985. Biogéographie des ammonites et évolution structurale de la Téthys au cours du Jurassique. Bull. Soc. Géol. France, 8 (1): 679-698.

Collignon, M. 1959. Atlas des fossiles caractéristiques de Madagascar. Fac. 3: Oxfordien. Serv. Géol. Madagascar, Tananarive: $46 \mathrm{Pl}$.

Dercourt, J., Zonenshain, L. P., Ricou, L. E., Kazmin, V. G., Le Pichon, X., Knipper, A. L., Grandjaquet, C., Sborshchikov, I. M., Boulin, J., Sorokhtin, O., Geyssant, J., Lepvrier, C., Boju-Duval, B., Sibuet, J. C., Svostin, L. A., Westphal, M. et Lauer, J. P. 1985. Présentation de 9 cartes paléogéographiques au $1 / 20.000000^{e}$ s'étendant de l'Atlantique au Pamir pour la période du Lias à l'Actuel. Bull.Soc.géol. France, (8), t.I, (5): 637-652.

\section{Plate I}

1. Perisphinctes (m Dichotomosphinctes) cf. luciae De Riaz. Specimen nr. KT.94/9/52. Wagad section, level 9. Incomplete specimen, presumably an adult microconch, showing evolute coiling and massive quadratic to rounded whorl section and biplicate, ribbing with common single ribs. Middle Oxfordian, middle Transversarium Zone. ?Schilli Subzone.

2. Perisphinctes (?m) cf. kiliani De Riaz. Specimen nr KT.94/8/28. Wagad section. level 8. Wholly septate specimen, presumably an incomplete microconch. Middle Oxfordian, middle Transversarium Zone. ? Schilli Subzone.

3. Perisphinctes ( $m$ Beraketites) cf. lehmani Collignon. Specimen nr KT.94/9/61. Wagad section, level 9. Incomplete, possibly juvenile specimen with almost a whole whorl of body chamber, showing evolute coiling, rounded to depressed whorl section and fine biplicate ribbing with occasional intercalaries and trifurcations. Thick parabolic nodes are visible at the beginning of the body chamber, after the constriction. Middle Oxfordian, middle Transversarium Zone. ?Schilli Subzone.

4. Perisphinctes (?M) gr. martelli Oppel-aguilonenesis Meléndez. specimen nr KT.94/6/112. Wagad section, level 6. Wholly septate, presumably a macroconch nucleus, showing moderately evolute coiling, compressed whorl section and dense ribbing with regularly biplicate and single ribs. Middle Oxfordian, Transversarium Zone. The martelli group Oppel spreads broadly between the Luciaeformis and Schilli Subzones.

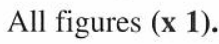


Plate I

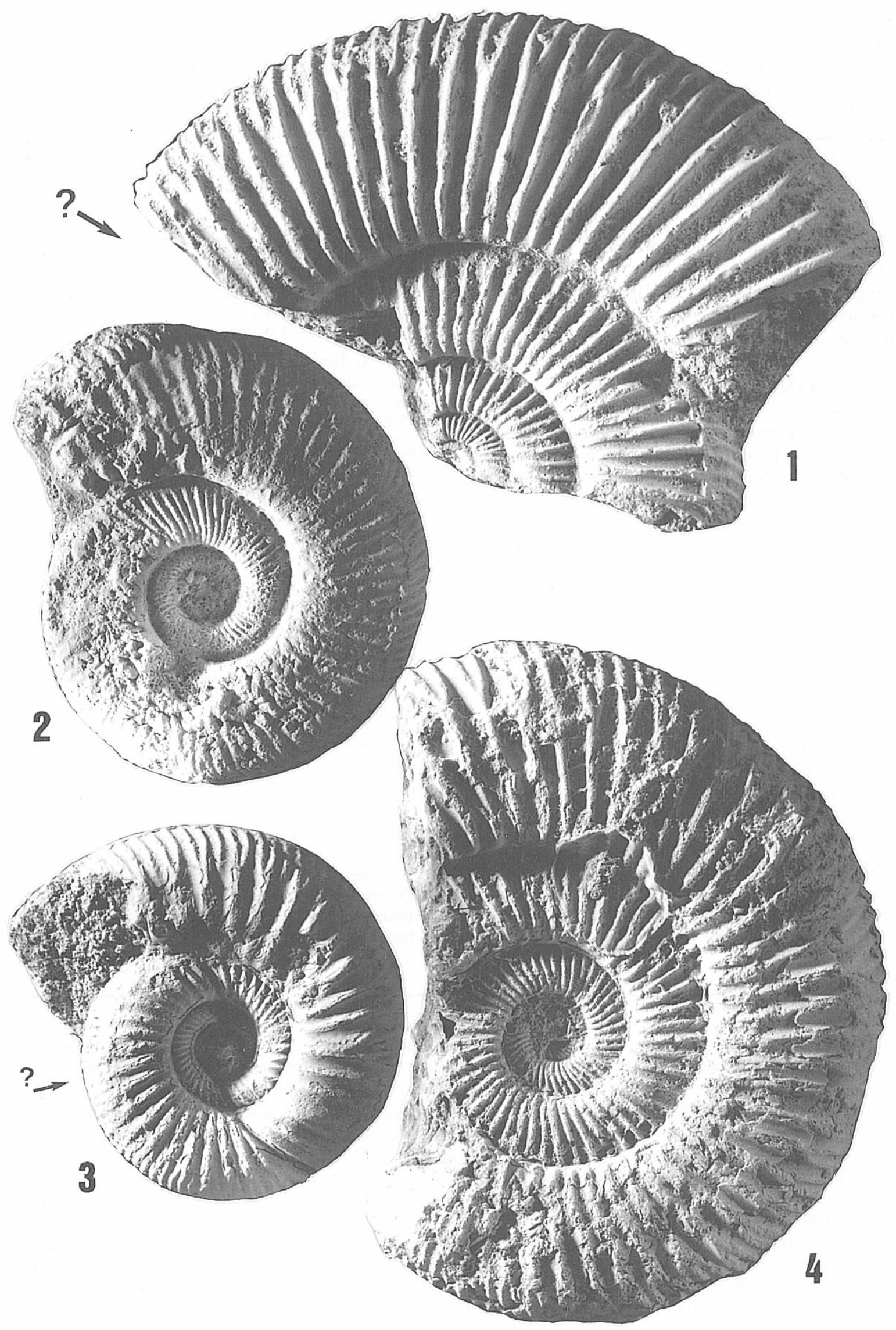


Enay, R. 1966. L'Oxfordien dans la moitié sud du Jura français, I. Etude stratigraphique. II Etude paléontologique. Nouv. Arch. Mus. Hist. Nat. Lyon: 1, 624.

Fernández-López, S. y Meléndez, G. 1994. Dispersión biogeográfica y tafonómica de ammonoideos filoceratinos hacia la Cuenca Ibérica durante el Jurásico Medio. Coloquios de Paleontología, 46, Ed. Complutense, Madrid: 129-142.

Krishna, J. and Cariou, E. 1990. Ammonoid faunal exchanges during Lower Callovian between the Indo - East-African and Submediterranean Provinces: Implications for the long-distance east-west correlations, Newsl. Stratigr., 23 (2): 109-122.

Krishna, J. and Cariou, E. 1994. The Tethyan Macrocephalitinae: evolutionary, environmental and dispersal strategies, Geobios, m.h.s., 15: 217-226.

Krishna, J. and Pathak, D. B. 1991. Ammonoid biochronology of the Kimmeridgian stage in Kachchh, India, Jour.Pal.Soc. India, 36: 1-13.

Krishna, J. and Pathak, D. B. 1993. Late Lower Kimmeridgian-Lower Tithonian Virgatosphinctinae of India: Evolutionary succession and biogeographic implications, Geobios, 15: 227-238.

Krishna, J., Pathak, D. B. and Pandey, B. 1994. Discovery of Middle and Late Oxfordian in Kachchh with the first ever approximation of Oxfordian/Kimmeridgian boundary in the Indian subcontinent, 4th International Oxfordian/Kimmeridgian Working Group Join Meeting, Lyon, Abstract, 10.

Meléndez, G. 1989. El Oxfordiense en el sector central de la Cordillera Ibérica (provincias de Zaragoza y Teruel). Institución Fernando el Católico; Instituto de Estudios Turolenses; Zaragoza, 418.

Meléndez, G. y Fontana, B. 1992. El género Larcheria (Perisphinctidae, Ammonoidea) en el Oxfordiense Medio de la Cordillera Ibérica, España. Rev. Española de Paleontología, No Extra: 137-147.

Meléndez, G. y Fontana, B. 1993. Biostratigraphic correlation of the Middle Oxfordian sediments in the Iberian Chain, eastern Spain. Acta Geologica Polonica, 43 (3-4): 193-211.

Sowerby, J. 1840. A notice respecting some forms collected in Kutch. Trans. Geological Society, London, 21 (5): 715-719.

Spath, L. F. 1928-1933. Revision of Jurassic cephalopod fauna of Kachchh (Cutch). Mem. Geol.Surv. India; Paleont. Indica, NS, IX, (2), I-VI: 1-945.

Waagen, W. 1873-75. Jurassic fauna of Kutch. The Cephalopoda. Mem. Geol.Surv. India; Paleont. Indica, I (1-4): 1-247.

Manuscrito recibido: 13 de diciembre, 1994 Manuscrito aceptado: 21 de junio, 1995 